\title{
EXPLORING THE CHALLENGES OF CONVENTIONAL BANKING PRACTICES AND PROSPECTS OF INTRODUCING AN ISLAMIC BANKING IN TAJIKISTAN: USING QUALITATIVE APROACH
}

\author{
Ashurov Sharofiddin ${ }^{1}$ \\ Ahmed Fauzi Bin Idris ${ }^{2}$ \\ Anwar Hasan Abdullah Othman ${ }^{3}$
}

\begin{abstract}
The purpose of this research is to explore the challenges of current banking practices in Tajikistan and investigate the prospects of introducing the new Islamic banking system. In which the Islamic banking may help in bring back the trust to the people for dealing with the banking system that will lead to enhance the economy growth. This study applied the qualitative method by conducting in depth interviews with the experts comprising seven respondents. The result of respondents showed that there is list of challenges that current banking practices facing in Tajikistan. This therefore encourage for introducing an Islamic banking system in Tajikistan. Among the challenges in Conventional Banking system that respondents identified are distrust, an interest-based (Ribâ) system, and long processes with complicated systems. This is because the listed challenges by respondents are crippling the entire banking system, if the authority is not concerning for catering the existed challenges. Moreover, the findings signify the challenges of conventional banking practice that the authorities of the country and practitioners must avoid when Islamic banks are established. In addition, the practitioners need to focus on improving the current banking practice to avoid the challenges identified in the study.
\end{abstract}

Keywords : Islamic banking, Conventional banking, Qualitative method, Tajikistan

\footnotetext{
${ }^{1}$ Post-Doctorate Researcher, International Islamic University Malaysia, anwar.hasan@live.iium.edu.my

${ }^{2}$ Professor, College University Insania (KUIN), ashurovsharaf@gmail.com

${ }^{3}$ Professor, College University Insania (KUIN), pengarahhea@insaniah.edu.my
} 


\section{INTRODUCTION}

By international standards, the most important and most remarkable feature of the Tajikistan's banking system is that it is still today a three-pillar system. There are three parts of the banking systems and correspondingly three important groups - or types - of banks that differ considerably compete severely for market share such as privet owned banks, governmental banks and non- banking institutions (micro finance) (World Bank Report Bank, 2015). However, there are still many challenges that facing by current banking practices in the country. To the best knowledge of researcher there is no empirical study has been done so far in the context of Tajikistan. Consequently, the researcher is tried to explore the challenges of conventional banking practices and contribute to the body of knowledge and more specific on Tajikistan banking industry to fill the literature gap which is identifying the challenges of conventional banking practices through qualitative approach (Coleman et al., 2012).

Despite the current conventional banking system has been around for more than ten decades in Tajikistan, however, the statistical information from the study by Falkingham, Baschieri, Evandrou and Grant, (2009), showed that less than $4 \%$ of the population deal with the current conventional banking system (World Bank, 2014). The exceptionally low level of the population dealing with the existing banking system slows economic growth and limits productivity. Accordingly, the most probably reasons are distrust, the riba-based system, complicated rules and regulations, high interest rate, poverty, and liquidity pressure among others. In addition, some people still do not trust the conventional system due to the lack of knowledge and awareness.

Therefore, this research attempts to explore the challenges of current banking practices and investigate the prospects of introducing the new banking system which is Islamic banking that can bring back the trust of the people to deal with the banking system as a tool to encourage people to deposit their money and invest in the banking sector that will enhance the economy, activate circulation and growth in the country throw qualitative approach. This study therefore conducted to answer the follow research questions.

1. What are the challenges of conventional banking practices in Tajikistan?

2. Why do the majority of Tajiks prefer not to deal with the current banking system in Tajikistan? 
3. Do you think the Islamic banking system can attract more customers if it is established in Tajikistan?

4. What are the challenges of current banking practices that will lead to introducing Islamic banking in Tajikistan?

5. How will the Islamic banking system contribute to society and economic development?

\section{LITERATURE REVIEW}

\subsection{The Concept of Challenges in Banking and financial Industry}

The concept of challenges has been explained by many different ways according to the different dictionaries being used it. Meantime, the challenges of conventional banking system have been explored by many researchers in different ways. For instance according to Honohan(1997) that he discussed the challenges is a banking system failures in developing and transition countries' economy. Furthermore, he linked these challenges to macro and microeconomics aspects. Unlikely, Mrak (2000) has been discussed challenges in broad meaning that a combination of transition and globalization process affects overall development of transition economies by different negative ways that requires changes and improvement. Nonetheless, he did not mention specific industry sector and region (Qian \& Allen, 2011,; Dellaert, 2012). On the other hand the challenges of banking system in China by Luo Ping(2003) that the failure to resolve the bank challenges would put China's financial system at risk and adversely impact on sustainable growth of the economy (Peng, 2006; Okozaki, 2007; Tobergte \& Curtis, 2013).

Moreover, banking system as an important financial institution need be straggle for improving and eliminating the challenges in order to fulfill its financial role. Hence, according to Nyantakyi, Sy, and Kayizzi-mugerwa(2015), banks play a crucial role in the economy as financial intermediary in the society for accelerating investment cycle and encouraging customers to deposit and contribute in economic growth. Thus, a banking system exist in order to screen potential borrowers, monitor customers' actions and efforts, provide liquidity risk insurance and create safe assets, offer the financial tools for customers for investing and attracting them with high efficiency and flexible rules and regulations (Tobergte \& Curtis, 2013). Besides, according to Dellaert (2012), banking industry is facing a lacking loyalty and distrust among their customers, providing more advance technology services, ensuring profitability and managing risk through the economic cycle. Moreover, there some researcher are explored 
and specified the banking challenges and focus particularly relevant challenges: the payment challenges, the markets challenges, and the regulatory challenge according to (Mersch, 2015,; Matsuo, Albertazzi, Greathouse and While 2016). However there are still many lacking improvement in the banking system that particularly pressured, as regulators continue to lack confidence in the industry (Kidder, 2013; Mountain 2014). So, the challenges of banking practices from other angle such as information security, launching with an uphill struggle to reestablish economic strength and customer trust, service efficiency and providing free environment that promote competition in the banking sector according to (Wehinger, 2009).

Besides, the European Bank has published a study about challenges of banking system on Mediterranean Partner Countries (MPC) and raised discussion challenges in coming years, the sector's role in promoting inclusive growth via job creation, domestic resource mobilization and financial stability will be ever more pronounced in that region (Lima, Hecibedel, Olejnik, 2011). In this regards, the challenges that lacking the banking practice in Tajikistan is a banking failure in creating job by providing financial tools for investing and contributing in economic growth. Similarly, moving to Central Asian region countries' banking challenges according to Pomfret (2009).

Therefore, the banks' balance sheets in worldwide and Central Asia region countries especially are not yet on a sound stability and future bank losses are still expected to be significant with further official support and changes will be needed to develop healthy banking sectors (Wehinger, 2009; Serrano, 2010). Likewise, according to Serrano, (2010) besides the financial institutions have become very significant and sophisticated in the way they operate. However, the products and services banking sector offers tend to be more and more problematic. Nonetheless, governments, regulators, and other institutions simply cannot manage to provide a solution and remedy for banking industry challenges in a satisfactory manner. As a consequence, many important issues are being overlooked by the banking institutions charged with directing our societies toward the common good(Serrano, 2010;Dullien, Kotte, \& Priewe, 2010; Coleman et al., 2012).

Consequently, it is very important for baking sector to grab public trust in order to proceeds more convenience in regards of dealing with challenges and satisfying clients. According to Devan(2013) the banking system can move more smoothly based on it is built on trust. As such, it is imperative for large financial institutions 
to protect their reputation in order to ensure the public's trust in holding and managing their financial activities. In recent years, banks have become more cautious and facing challenges, particularly in the wake of the financial crisis, when a number of large, well-respected financial institutions were the subject of highly publicized investigations of fraud, financial mismanagement, and misleading. Subsequently, banks have adopted many measures to protect their reputation and keep themselves away from public clashes (Kidder, 2013).

Furthermore, according to Aliqoriev(2013), the challenges of the banking practices in CIS countries authorities have addressed some critical banking challenges such as the government's role in the banking system, transparency and the absence of trust to have potential clients. In particular, uncertainties about policy implementations complicate banks' operations and liquidity pressure (Coleman et al., 2012). Nevertheless, the studies mentioned above have not discussed and proposed any solution for those challenges, a gap that this study aims to fill. On the top of that, according to (Kidder, 2013) in order to achieve the high level of economic growth and sustainable profitability of banking industry it is urgent to eliminate the main challenges in the banking industry such as high interest rates, rebuilding asset quality and strengthening their capital adequacy by enriching and increasing the business value of customer relationships and restoring public confidence and trust towards the banking industry (Mallorca, 2007,; Ratings 2014) but did not discuss any potential solution with regard to these banking challenges. In summary, these challenges may be summarized in three parts such as in terms of regulatory and supervisory such as intervention of the government, complicated rules and regulations, operational challenges such as high interest rate, liquidity pleasure, insufficient services and riba based system.

\subsection{The Challenges of Banking Practices in Tajikistan}

The concept of challenges was explored that it is a problem and potential failure that facing the banking industry in worldwide. Hence this research is adopting the concept which has explained as a threat and problems facing the current banking practices due to avoiding the majority customers to deal with current banking industry in the country and shortcomings of financial role as a financial intermediary institution in Tajikistan. In this regard, according to Jonson 2000, and Nesvetailova, 2014, The main sector that collapsed during collapsing of former Soviet Union was the economic sector, specifically the banking industry. The banking sector lost the trust of its clients which is deemed as main challenges to the financial institutions that lead to majority of population do not deal with 
banking industry. Beside the economic development and financial enhancement, there is still many other banking challenges in Tajikistan that made majority to avoid dealing with banking sector, which is indication of the unsuccessfulness of the banking system to grab during all these time the trust of customers towards banking industries (World Bank Report Bank, 2015). Furthermore, this unsuccessfulness of the current banking system leads to lack of economic growth due to involving the minority of population into investment and economic flow with banks. Therefore, it is banking sector responsibility to regain the trust of the majority of the population in their activities and in the same time authorities need to give some more flexibility to the banks for acting freely without intervention of the government to the banking industry according to (Asia Development Bank, 2013). In addition there is a need of services development and infrastructure that can contribute in poverty reduction by providing more financial tools for investing and creating more employment rate in the country (World Bank report, 2014,; Tadjbakhsh 2008,; The World Factbook, 2015,; Brbone et al., 2010). Therefore, another challenge that facing the banking practice in Tajikistan is intervention of the authorities into banking activities and limiting banking role in the country (Chorshanbiyev, 2013b; Shirinov, 2013).

Furthermore, the Ministry of Finance of Tajikistan stated that the government borrowed over US\$2 billion in foreign debt which is equal to approximately $30 \%$ of the GDP and it is increasing year after year. Although, the borrowing money as a government is almost common among the international community, but if the banking industry shortcoming to provide enough found to big corporation and to relocate these borrowed money wisely, then will be more problematic and challenging to the entire system specifically banking sector. Therefore, the current banking system in the country that is facing serious challenges to provide enough financial tools for creating job opportunity and encouraging economic growth, that also lead banking industry not playing its financial intermediary role properly and there will deepen the distrust among customers and banks. In this regard, "Asia-Plus" Bibolov (2013) that the challenges of loan default rate have remained quite high in the Central Asia region, in particular Tajikistan and Kazakhstan (Asia Development Bank, 2013). Therefore, the banking system in the country is almost losing the control over the financial activities and financial betterment of the country which is really challenging the banking sector in Tajikistan. What's more, this loss of control and the ability to play a crucial role as a financial intermediary will lead to more financial instability, insecurity, lacking financial activities and distrust towards their customers in the country. So, the central bank of the country and other authorities need urgently to call for serious 
solution or restructuring the banking system or introducing a new banking system in the country to reactivate the financial intermediary role in the country, otherwise will be serious financial and economic panic in the country (Ahrens \& Hoen, 2013).

Likewise, according to Akramov and Shreedhar (2012), there is lack of financial intermediary, stability, productivity, and the disconnection between investor and savers are major challenges facing the current banking practices in Tajikistan. Therefore, it is the right time for re-thinking to restructure the banking system and focusing on eliminating these challenges from the banking sectors is an urgent need for keep the financial intermediary active and productive in the country. Most important of all, the current banking system, mentioned by Ergasheva (2014), is very weak facing a financial crisis and turmoil and needs drastic restructuring and development for the financial betterment of the country.

In summary, according to the previous studies mentioned above there are different challenges that beset the current banking practices in Tajikistan which has failed to provide enough financial tools for further investment and opportunities. One of the main challenges is the reluctance of the majority of the population to deal with the current banking practices for various reasons such as distrust, poverty, complicated rules and regulations, high interest rate and ribabased system among others that violate the beliefs of the Muslim majority in the country. Also, although there are many financial supports and help receiving by the financial industry from the international financial institutions such as IMF, World Bank and others, yet there is a significant lack of financial intermediaries in Tajikistan's banking sector. So, to the best knowledge of the researcher there is no empirical study done so far to identify the challenges of conventional banking practices in Tajikistan. Therefore, this study as a first empirical study aims to fill this gap by interviewing practitioners and obtaining their points of view.

\section{RESEARCH METHOD}

The research aimed to explore the challenges of the conventional banking system in Tajikistan applying the qualitative method to collect data by conducting in depth interviews with the experts comprising seven respondents and their identities remain confidential in line with the ethical norms and considerations. The respondents of the qualitative method and those who participated in the interview were defined by specific coding such as Specialists (S1, S2); two of them are specialists in the field of conventional banking system, who were familiar with 
Islamic banking and finance. Practitioners (P1, P2) are in banking in Tajikistan. The Student (ST1) is a postgraduate student at the International Islamic University, Malaysia, in the area of banking and finance and he is from Tajikistan and aware of conventional banking practices there. Sharamic Scholar (SH1) is a Sharlar scholar who is aware of financial banking practices in Tajikistan.

Interview was the instrument utilized to generate information regarding qualitative data from the respondents. The interview covered the above research questions and involved experts in the field of current banking practice in Tajikistan and Islamic banking system, Sharî́ah scholars, and practitioners. The interview was semi-structured and responses were recorded and documented for analysis. In the qualitative interview, seven respondents participated. The selection of respondents for the interview was largely based on expertise. Those believed to represents an informed opinion, willingness of the respondents and availability of time, and resources among others were selected to be interviewed. According to Schaefer and Dervin (2003), expert sampling is a subject of purposive sampling used for two reasons: producing the views of people with specific expertise, and to provide evidence for the validity of research outcomes. On the other hand, according to Oliver (2006), expert proposal sampling is a form of non-probability sampling in which decisions concerning the individuals to be included in the sample are taken by the researcher, based upon a variety of criteria which may include specialist knowledge of the research issue, or capacity and willingness to participate in the research. Some types of research design necessitate researchers taking a decision about the individual participants who would be most likely to contribute appropriate data, both in terms of relevance and wisdom(Richard Andrei \& Julia, 2006).

\section{FINDINGS AND DISCUSSION}

These study findings were derived from the statement made by the experts. The overall respondent and their themes of challenging are reported in table 4.1. 
Table 4.1

Summary of Qualitative Results

\begin{tabular}{|c|c|c|c|c|c|}
\hline $\begin{array}{c}\text { Respon- } \\
\text { dents }\end{array}$ & $\begin{array}{c}\text { Question } 1 \\
\text { What are the } \\
\text { challenges of } \\
\text { CB? }\end{array}$ & $\begin{array}{c}\text { Question } 2 \\
\text { Why Majority } \\
\text { are not dealing } \\
\text { with CB? }\end{array}$ & $\begin{array}{c}\text { Question } 3 \\
\text { Establishment of } \\
\text { IB can attract } \\
\text { more } \\
\text { customers? }\end{array}$ & $\begin{array}{c}\text { Question } 4 \\
\text { What are the } \\
\text { challenges of } \\
\text { CB lead to } \\
\text { Introduce an } \\
\text { IB? }\end{array}$ & $\begin{array}{l}\text { Question5 } \\
\text { How IB can } \\
\text { contribute to } \\
\text { Economic } \\
\text { Development }\end{array}$ \\
\hline 1 & $\begin{array}{l}\text { Distrust } \\
\text { Intervention } \\
\text { of the } \\
\text { government } \\
\text { Poverty } \\
\text { Ribâ System } \\
\text { Unawareness }\end{array}$ & $\begin{array}{l}\text { High interest } \\
\text { rate } \\
\text { Distrust } \\
\text { Intervention of } \\
\text { the government } \\
\text { Poverty } \\
\text { Ribâ System } \\
\text { Unawareness }\end{array}$ & $\begin{array}{l}\text { Yes because of: } \\
\text { Majority Muslim } \\
\text { Distrust towards } \\
\text { Conventional } \\
\text { No because of: } \\
\text { Duplication of } \\
\text { conventional } \\
\text { Unawareness }\end{array}$ & $\begin{array}{l}\text { Lack of } \\
\text { awareness } \\
\text { Competition } \\
\text { Distrust } \\
\text { toward CB }\end{array}$ & $\begin{array}{l}\text { Yes because of : } \\
\text { Historical } \\
\text { Success of IB } \\
\text { Create new job } \\
\text { Capital Inflow } \\
\text { Profit \& Loss } \\
\text { sharing }\end{array}$ \\
\hline 2 & $\begin{array}{l}\text { Distrust } \\
\text { Intervention } \\
\text { of the } \\
\text { government } \\
\text { Poverty } \\
\text { Ribâ System } \\
\text { Unawareness }\end{array}$ & $\begin{array}{l}\text { High interest } \\
\text { rate } \\
\text { Distrust } \\
\text { Intervention of } \\
\text { the government } \\
\text { Poverty } \\
\text { Ribâ System } \\
\text { Unawareness }\end{array}$ & $\begin{array}{l}\text { Yes because of: } \\
\text { Majority Muslim } \\
\text { Distrust towards } \\
\text { Conventional } \\
\text { No because of: } \\
\text { Duplication of } \\
\text { conventional } \\
\text { banking } \\
\text { Unawareness }\end{array}$ & $\begin{array}{l}\text { Lack of } \\
\text { awareness } \\
\text { Competition } \\
\text { Distrust } \\
\text { towards CB } \\
\text { Double } \\
\text { Taxation }\end{array}$ & $\begin{array}{l}\text { Yes because of: } \\
\text { Historical } \\
\text { Success of IB } \\
\text { Create New Job } \\
\text { Capital Inflow } \\
\text { Profit \& Loss } \\
\text { sharing }\end{array}$ \\
\hline 3 & $\begin{array}{l}\text { Distrust } \\
\text { Intervention } \\
\text { of the } \\
\text { government } \\
\text { Poverty } \\
\text { Ribâ System } \\
\text { Unawareness }\end{array}$ & $\begin{array}{l}\text { High interest } \\
\text { rate } \\
\text { Distrust } \\
\text { Intervention of } \\
\text { the government } \\
\text { Poverty } \\
\text { Ribâ System } \\
\text { Unawareness }\end{array}$ & $\begin{array}{l}\text { Yes because of: } \\
\text { Majority Muslim } \\
\text { Distrust towards } \\
\text { Conventional } \\
\text { No because of: } \\
\text { Duplication of } \\
\text { conventional } \\
\text { banking } \\
\text { Unawareness }\end{array}$ & $\begin{array}{l}\text { Lack of } \\
\text { awareness } \\
\text { Competition } \\
\text { Distrust } \\
\text { towards CB } \\
\text { Double } \\
\text { Taxation }\end{array}$ & $\begin{array}{l}\text { Yes because of: } \\
\text { Historical } \\
\text { Success of IB } \\
\text { Create New Job } \\
\text { Capital Inflow } \\
\text { Profit \& Loss } \\
\text { sharing }\end{array}$ \\
\hline 4 & $\begin{array}{l}\text { Distrust } \\
\text { Intervention } \\
\text { of the } \\
\text { government } \\
\text { Poverty } \\
\text { Ribâ System } \\
\text { Unawareness }\end{array}$ & $\begin{array}{l}\text { High interest } \\
\text { rate } \\
\text { Distrust } \\
\text { Intervention of } \\
\text { the government } \\
\text { Poverty } \\
\text { Ribâ System } \\
\text { Unawareness }\end{array}$ & $\begin{array}{l}\text { Yes because of: } \\
\text { Majority Muslim } \\
\text { Distrust towards } \\
\text { Conventional } \\
\text { No because of: } \\
\text { Duplication of } \\
\text { conventional } \\
\text { banking } \\
\text { Unawareness }\end{array}$ & $\begin{array}{l}\text { Lack of } \\
\text { awareness } \\
\text { Competition } \\
\text { Distrust } \\
\text { towards CB } \\
\text { Double } \\
\text { Taxation }\end{array}$ & $\begin{array}{l}\text { Yes because of: } \\
\text { Historical } \\
\text { Success of IB } \\
\text { Create New Job } \\
\text { Capital Inflow } \\
\text { Profit \& Loss } \\
\text { sharing }\end{array}$ \\
\hline 5 & $\begin{array}{l}\text { Distrust } \\
\text { Intervention } \\
\text { of the } \\
\text { government } \\
\text { Poverty } \\
\text { Ribâ System } \\
\text { Unawareness }\end{array}$ & $\begin{array}{l}\text { High interest } \\
\text { rate } \\
\text { Distrust } \\
\text { Intervention of } \\
\text { the government } \\
\text { Poverty } \\
\text { Ribâ System } \\
\text { Unawareness }\end{array}$ & $\begin{array}{l}\text { Yes because of: } \\
\text { Majority Muslim } \\
\text { Distrust towards } \\
\text { Conventional } \\
\text { No because of: } \\
\text { Duplication of } \\
\text { conventional } \\
\text { banking } \\
\text { Unawareness }\end{array}$ & $\begin{array}{l}\text { Lack of } \\
\text { awareness } \\
\text { Competition } \\
\text { Distrust } \\
\text { towards CB } \\
\text { Double } \\
\text { Taxation }\end{array}$ & $\begin{array}{l}\text { Yes because of: } \\
\text { Historical } \\
\text { Success of IB } \\
\text { Create New Job } \\
\text { Capital Inflow } \\
\text { Profit \& Loss } \\
\text { sharing }\end{array}$ \\
\hline
\end{tabular}




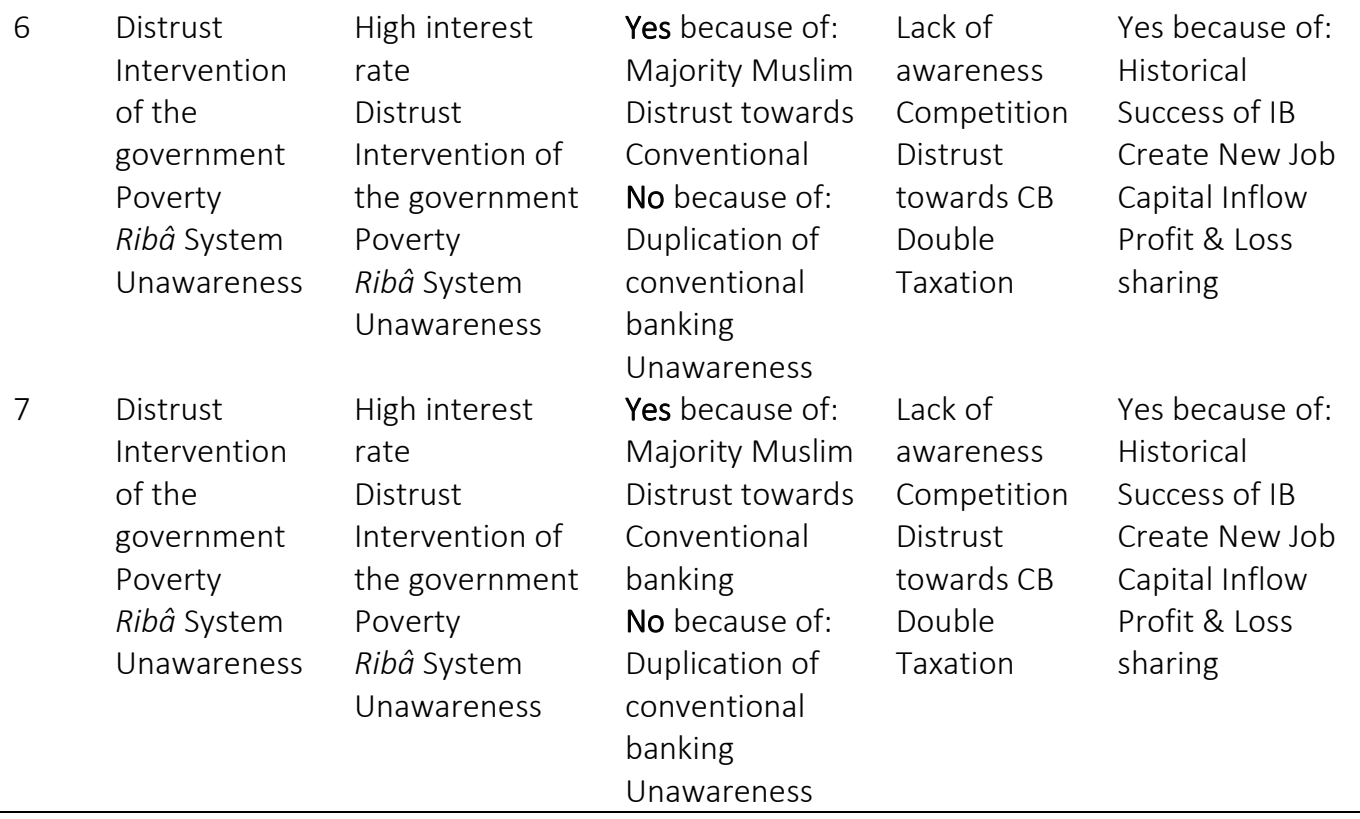

\section{What are the main challenges of conventional banking practices in Tajikistan?}

"One of the main challenges of the conventional banking practice in Tajikistan is the high interest rate which makes it difficult to attract customers. Since the interest rate is very high in the country it has led people in Tajikistan to avoid dealing with banks for utilizing services such as borrowing. On the other hand, the people of Tajikistan do not trust the current banking practice in Tajikistan as it is unpredictable and anything can happen at any time, especially under current international financial instability. Therefore, they prefer to save their money at home rather than deposit it in banks. In addition, the complicated rules and regulations, requirements and documentations, the slow and long processing procedure are among challenges of the current banking practice in Tajikistan". (S1)

"I prefer to answer this question through the historical perspective, because if you want to know the challenges of the conventional banking system in Tajikistan you have to see it from the historical angle. During the early $20^{\text {th }}$ century, Tajikistan was one very poor and economically backward and it remained like that during the latter part of the $20^{\text {th }}$ century when it was under the communist regime. Starting from the early $21^{\text {st }}$ century and getting independence from the communist regime it experienced a civil war that caused the collapse of the entire system including the financial and banking system. Thereafter, Tajikistan started to build a new system and adopted the capitalist system that is why Tajikistan's banking system is still not productive. In addition, the Tajikistan 
currency was changed three times until now and that caused people to lose millions in value of their money. As a result, even now Tajikistan's financial system is facing many challenges such as unqualified staff, high poverty rate, little confidence in banks, and little awareness of using banking services, etc. (S1)

"Although it is common that the government institutions such as education sector, legal sector, economic sector and financial sector are supposed to serve the population's interest and meet their needs, unfortunately, Tajikistan's legislation is still centralized and the institutions cannot provide services independently and depend on a top down system including the banking sector and central bank. Therefore, the central bank is highly dependent on the higher authorities and the government's permission to provide services, even those that could be beneficial for its customers and society. Also, there is another reason for this problem such as distrust among Tajikistan's population of the banking sector as it is based on interest (Ribâ). Moreover, the population historically prefers to save their money in their homes rather than deposit it in banks. This is because we have experienced many bank bankruptcies which have caused many people to lose their money plus the effects if the currency bring changed three times". (R1)

"As we can see, the banking sector in Tajikistan is not developed because there are many challenges facing the banking sector in the country. The main challenge in the country regarding banking is the population's distrust of the banking practices either in terms of management or processes. Moreover, the very high interest rate is deemed another major challenge that has caused people to avoid dealing with the banking sector to borrow money. In addition, there is no creativity in the banking sector like in other countries and this has hampered its development." (S2)

"The main challenges of conventional banking in Tajikistan are highly dependent on the individual high authority and political power of the rules and regulations and as a result the central bank and banking sector are not working independently. As a result, the banking

services and activities are serving and providing facilities for the high authorities only, but not for ordinary citizens. In addition, the poverty line in the country is very high and people do not have enough money to save in the banks while at the same time the banking sector is not ready to provide facilities and products that can attract the majority of the population. Finally, the population in the country does not trust the banking sector". (P1) 
"I think the main challenges of conventional banking practice are the reluctance of the majority of the people to deal with banks due to bad past experience with banks which has increased the distrust of the people. The current banking activities are just transferring remittances from overseas to the country while the other banking services and products cannot attract customers". (ST1)

"I think the main challenges of conventional banking practice are the majority of the population living under the poverty line and $40 \%$ of the population are working overseas and the remittance transfer is consumed. Furthermore, there is mistrust/ distrust among the majority of the population in conventional banking practices". (P2)

According to the respondents' opinions to the first question, all respondents agreed on the challenges of the conventional banking practice in Tajikistan such as the distrust of the majority of the population in conventional banking practices. In addition, all respondents agreed that the intervention of the government in the banking practice is another issue and dependence of the banking sector on government decisions in order to provide services and products to customers and clients is a major challenge. The majority of the population are living below the poverty line, which is another issue raised by the respondents. Furthermore, the Ribâ system is prohibited by Islam, which is another challenge of conventional banking since the majority of Tajikistan's population are Muslim in the country.

Another challenge was mentioned by respondent $\mathrm{SH} 1$ and that was the low confidence in and little awareness of conventional banking practice due to the historical collapse of the system that triggered the changing if the currency and the loss of huge savings. In addition, this respondent mentioned that the unqualified staffs in the banking sector are another challenge.

\section{Why do the majority of Tajiks prefer not to deal with the current banking system in Tajikistan?}

"As we mentioned earlier, the challenges are the same reasons that made the majority population of Tajikistan not to deal with current banking practices. These include distrust in the conventional banking system, dealing with interest (Ribâ), long process and complicated rules and regulations, high poverty rates and not linking between bills payment and other obligation payment through the banking system". (S1) 
"As I answered in the first question and listed some challenges of the conventional banking system in Tajikistan, like the majority of the population is living below the poverty line therefore, they do not have enough money to deposit as savings in banks. In addition, the banking system in Tajikistan could not attract the population's interest to deal with them and there are many reasons behind this distrust in banks such as dealing with interest (Ribâ) which violates their Islamic beliefs, the awareness of the population is poor toward dealing with banks and how to benefit from the banking system, the interest rate is very high which is more than $25 \%$, etc. These are the main reasons behind the majority of the population not dealing with banks". (SH1)

"This is because the majority of the population are living in poverty and don't have enough money to deposit in banks. At the same time, Tajikistan is a Muslim majority country and the current banking sector is violating their beliefs due to its dealing with Ribâ-based activities. Additionally, there is a distrust of people toward the banking sector due to bad experience during the collapse of the former Soviet Union and last international financial crisis that in 2008". (R1)

"The same challenges as we discussed earlier is the reason behind the decision of the minority of the population not dealing with current banking in Tajikistan". (S2)

"Based on the governmental statistics, 98\% of the population are Muslim and they do not agree to deal with a Ribâ-based system. Tajikistan's economic environment is facing more challenges and turmoil and there is no insurance system available to compensate them if they should suffer losses". (P1)

"I think there are many reasons for the majority avoiding dealing with banks in Tajikistan such as the high interest rate and intervention of the government in the banking sector and politics influencing banking activities". (ST1)

"The same reason we mentioned above is the main factor that causes the majority not to deal with current banking practice. In addition, the other important factor is that the conventional banking is Ribâ-based and the majority of the population are Muslim and do not accept a Ribâ-based system for religious reasons". (P2)

According to the responses to question number two, all the respondents repeated their answers from the first question such as distrust, high interest rate, high level of poverty, dependence of the banking sector on high authority of the 
government to decide, the Ribâ-based system and others. However, the respondent (P1) added another reason for the majority of the population avoiding dealing with the banking sector which is the non-existence of an insurance system to protect the wealth of the population and to encourage them to deal with banks.

\section{Do you think the Islamic banking system can attract more customers if it is established in Tajikistan?}

"I believe yes to some extent only, because the majority of Tajikistan's population is Muslim and if the banking system proves that it is working based on the Sharî'ah rules; otherwise there will not be much attraction to deal with Islamic banks, because there will not be much difference between conventional and new Islamic banks. In addition, if the introduced Islamic bank could make some sort of products to attract remittance to be used through Islamic bank, the public might be interested". (S1)

"I totally agree with you that, if the Islamic banking system is established in Tajikistan it will attract more customers compared to the conventional system due to many reasons. The reason is very simple in that the challenges which cause the majority of the population to not deal with conventional banking will be eliminated by establishing an Islamic bank which will attract more customers and depositors. In the case of dealing with interest (Ribâ), it is not allowed in the Islamic banking system and this will attract more customers due to Tajikistan's Muslim majority. At the same time, the profit and loss sharing system under Islamic banking system can attract many customers. In addition, the flowing of capital from the international Islamic banking institution will be another reason to attract more customers". (SH1)

"I can say that yes it can attract more customers and cannot as well. Yes it can be successful if the Islamic bank will be established and can proceed based on the Sharî́ah rules and promote the products such as Musharalkah and Mudarabah and others that will promote and facilitate dealing with Islamic bank whether as an investor or just a normal customer. In contrast, there is a possibility that it cannot attract customers because of political issues that may accuse the Islamic bank's customers of being terrorists. People will be scared to deal with Islamic banks because any Islamic name is very sensitive in Tajikistan society". (R1) 
"Surely, I strongly believe that establishing the Islamic banking sector is able to increase its customers and clients for the following reasons: firstly, the majority of Tajikistan is Muslim and the level of religiosity is increasing as well and as we know that dealing with Ribâ is one of the greatest sins in Islam. Secondly, the product and activities that will be promoted are Shari' ah-based and reasonable for different levels of customers and clients. The important notice I should say here is that it is depending more on whether it will be established as a window or fullfledged". (S2)

"Yes, I believe there will be more customers and users for Islamic bank if established in the country, because the majority of the population in the country is Muslim. On the other hand, if the Islamic bank works just to duplicate the conventional banks then people will stay away like they do with the conventional banks. Moreover, the government should provide and promote the understanding of Islamic banking and increase the awareness of people toward facilities and activities of Islamic banks. Furthermore, the government and high authorities need to promote the social norm and culture of using Islamic banks". (P1)

"Since the current conventional banking system in the country cannot satisfy the customers' interest then there is a need for an alternative banking system which is the Islamic bank. Therefore, if the Islamic banking is introduced in Tajikistan, then definitely Islamic banks can increase their customers in the country. However, the government should develop the awareness of people and help encourage a culture of using Islamic bank in the country. Moreover, if the Islamic bank covers the challenges of conventional banking, then they can attract more customers". (ST1)

"Yes, definitely, if the Islamic bank is established in the country it will attract more customers because as a Muslim majority country and also attract the 14\% that dealing so far with conventional banking".(P2)

According to the respondents' comments for question three, all respondents agreed on some issues such as the establishment of Islamic bank will attract more customers in Tajikistan because of the Muslim majority. Moreover, they mentioned that there is one condition to attract more customers, which is, when an Islamic bank isestablished, it must be Sharî‘ah-based rather than duplicate the conventional system. However, some respondents mentioned that there is lack of Islamic banking awareness and social norm in the country. Therefore, the government should increase awareness of the people about the Islamic banking 
system and social norms toward using and understanding Islamic banking in Tajikistan, otherwise it will not be successful.

\section{What are the challenges of current banking practices that will lead to introducing Islamic banking in Tajikistan?}

"The challenge facing the conventional banking system in Tajikistan will cause the introduction of an Islamic bank and eliminate the distrust toward current banking. Therefore, the government should increase the level of banking awareness, understanding, products and activities of Islamic banks. On the other hand, I think if conventional banking introduced more simple activities with customers it can compete with Islamic banks in the beginning, but later it will not be able to compete". (S1)

"The current banking practice in Tajikistan could not get the trust of the population and therefore, there is a need to introduce an Islamic bank as new and alternative banking system in Tajikistan. The current banking activities in Tajikistan are based on debt financing which has caused many investors to lose both money and confiscated property as a result there is a need to introduce an Islamic bank in the country. Dealing with interest (Ribâ) is another reason behind the introducing of an Islamic bank in the country in order to attract more deposits to the banking sector. On the other hand if an Islamic bank deals in the same way as conventional banking system using an interest-based system then there will be no point in introducing a new system". (SH1)

"I believe the main challenges of introducing an Islamic bank in Tajikistan is the poor level of awareness of Tajik society and population regarding Islamic bank. Therefore, the government should promote and try to increase the level of awareness of people toward Islamic bank. With regard to conventional banking practice I don't think it will challenge the introduction of Islamic bank". (R1)

"I believe if the Islamic bank is introduced as a full-fledged system in Tajikistan, then there will be challenges for conventional banking to accept another system to compete with it in the country. In Addition there is the possibility that current banking practice will be affected by the stiff competition and will challenge the introduction of an Islamic bank in the country. On the other hand, the banking legislation and central bank rules and regulation should allow Islamic banks to proceed with different laws and regulation matching its objectives 
otherwise the Islamic bank's contracts and services will be more expensive, and double taxation will appear". (S2)

"The banking acts and legislation are the main challenges of introducing an Islamic bank, because the political power is above legislation and rules. So, introducing an Islamic bank should work independently and there should be no intervention by political interests "( $P 1)$

"The main challenges of introducing an Islamic bank in the country are intervention of the government and politics, so the Islamic bank is supposed to work independently within special laws and treatment from the central bank". (ST1)

"As we discussed earlier, the interest rate is very high in the country and will be the main challenge that will cause the introduction of an Islamic bank. At the same time, the tax structure should be changed in order to avoid double taxation to deal with an Islamic bank". (P2)

According to the respondents' comments, all respondents have different views on question four, even though they have similar perceptions on a few issues. The respondents (S1) and (R1) agreed that there is lack of awareness and understanding toward adopting an Islamic bank as a new system in the country. Therefore, the government should increase the level of awareness. On the other hand, the respondents (S1) and (S2) agreed that if the Islamic bank is established in the country there will be stiff competition between the two banking systems. However, respondent $\mathrm{SH} 1$ believed that the distrust of the population in conventional banking is an incentive to establish an Islamic bank to satisfy all needs of customers and at the same time duplicate conventional banks for debt financing while the Ribâ system is another challenge for introducing an Islamic bank in the country. Moreover, the respondents (P1) and (ST1) mentioned that the intervention of the government in the banking sector is another challenge facing the introduction of an Islamic bank. Lastly, the respondents (S2) and (P2) believed that the tax structure is another challenge for introducing an Islamic bank in the country and needs to be amended in order to suit the nature of Islamic banking. 


\section{How will the Islamic banking system contribute to society and economic development?}

"As we know the main aim of Islamic bank is providing economic justice in society and distribution of wealth among the population. As it is clearly described by many Quranic verses and Hadith, there should be Islamic economics in promoting the brotherhood principle and not accumulate the wealth among only a few and fulfilling Shari'ah objectives. Therefore, if Islamic banking is established in Tajikistan and operates based on pure Sharî'ah's principles such as profit and loss sharing, then definitely establishing an Islamic bank will give the country an economic boost and create a lot of jobs and will enhance the social network and contribute to a decrease in the poverty rate."

"Tajikistan should start from the Islamic banking windows and develop them such as done in Malaysia and other countries, instead of full-fledged Islamic bank as is the case in Iran and Sudan. This will help the country to develop the banking sector faster and to be successful in the country and show to customers that a really successful Islamic banking system is possible and need not be just a duplicate of the conventional banking system but a different system in accordance with Sharî‘ah principles".(S1)

"It is very clear and I strongly believe thatbanks are a financial institution that will channel the money from the savings sector to investor sector therefore establishing of Islamic bank will play the same role in Tajikistan as a Muslim majority country and finally will impact the economic sector positively by creating more jobs and financial activities. At the same time Islamic bank will attract depositors and customers because the offered services match their beliefs. At the same time, Tajikistan is a rich country with natural resources but needs a lot of capital to invest and develop; therefore, establishing an Islamic bank in Tajikistan will attract capital flow from the Islamic countries which will impact positively on Tajikistan's economy". (SH1)

"Definitely, as we see the conventional banking practice in Tajikistan is unable to fulfil the needs of its customers and clients, but Islamic banking system has been proven all around the world not just in Muslim countries but even in nonMuslim countries as well such as UK and others that have contributed and have accelerated the development of economics in society. Therefore, if Islamic bank is established in Tajikistan and introduced properly to the population, I strongly believe that it will contribute in developing Tajikistan. At the same time, once the 
economic is developed in the country it will enhance society as well. The most important thing is the government must increase the level of awareness of the population regarding an Islamic bank and promote dealings with the Islamic bank in social activities and culture". (R1)

"Of course, I believe the Islamic bank will contribute to economic development of the country and this is based on the good experience of the countries that have adopted an Islamic bank for some time. Again, I would repeat that if the Islamic bank is introduced as a full-fledged system it can contribute more rather than be established just as a window. Moreover, the contribution of introducing an Islamic bank in economic development depends mostly on whether it will be introduced as a pure Islamic system or just a duplicate of the conventional bank as the former will contribute more and the letter one cannot contribute as it is supposed to. However, establishing any system can only properly fulfil its duties when it proceeds within rules and regulations without the influence of any other external power such as political power, high authority, etc. Therefore, introducing an Islamic bank will be a success in the country when it proceeds just within laws only". (S2)

"Yes, the main objective of the Islamic bank is reducing poverty and helping society and contributing to the development of the economy in the country. However, I did not see any Islamic bank in the world achieving this objective, unless the introduction of an Islamic bank in Tajikistan will be done as a purely Islamic entity and not just a duplicate of a conventional bank." (P1)

"In my opinion, the Islamic banking activities and products can really contribute to economic development and will enhance social progress. For example, if we see in Malaysia and other countries which have adopted Islamic banking and how it has helped in economic and social development. This is because Islamic banks will not focus on accumulating profits only, but will take care to reduce the level of poverty and contribute to social welfare". (ST1)

"Yes, I do believe that establishing an Islamic bank will contribute to developing the economy and enhancing the level of society. For instance, 16-17 October was OIC countries economic forum in Tajikistan to discuss the investment in different Islamic countries. Therefore, if an Islamic bank were to be established in the country as an OIC member, it will definitely attract foreign capital to be invested in the country. Ultimately, it will create more jobs and economic progress in the country". (P2) 
According to the respondents' answers to question five, they agreed that the establishment of an Islamic bank in Tajikistan will contribute to economic development and enhance social welfare. The historical success of Islamic banks in other countries is the best example of the contribution of Islamic banks to social and economic development. The establishment of an Islamic bank will create more jobs due to the nature of its products which is based on profit and loss sharing. Therefore, it will create more jobs in the country and will attract more capital from other Muslim and non-Muslim countries because of opportunities to invest in the country, according to respondents $\mathrm{P} 2$ and $\mathrm{SH} 1$. According to respondent $(S 1, R 1, P 1)$, the contribution of Islamic bank in the country is highly dependent on whether it is Sharî‘ ahbased or simply duplicates the conventional system. It will contribute more once it is established based on sharî‘ah objectives.

\section{CONCLUSION}

In Conclusion, Tajikistan is a Muslim majority country located in Central Asia where Islamic finance has yet to be established. However, given the challenges of current banking practices in the country and the on-going adverse effects on the banking industry, the authorities are looking to rectify the unproductive banking and financial system in the country. Accordingly, the purpose of this research is to explore the challenges of current banking practices and investigate the prospects of introducing the new banking system which is Islamic banking that can bring back the trust of the people to deal with the banking system as a tool to encourage people to deposit their money and invest in the banking sector that will enhance the economy, activate circulation and growth in the country. Furthermore, to explore the challenges of the conventional banking system in Tajikistan the researcher applied the qualitative method to collect data by conducting in depth interviews with the experts comprising seven respondents. However, the result of respondents showed that there is list of challenges that facing current banking practices in Tajikistan that lead to the neediness of the introducing an Islamic bank there. This is because the listed challenges by respondents are crippling the entire banking system, if the authority is not concerning for catering the existed challenges. Among the challenges that respondents identified are distrust in conventional banking, an interest-based (Ribâ) system, and long processes and complicated systems, among others. In light of these revelations, the general belief was that the establishment of Islamic banks in the country would contribute to economic development and social welfare enhancement. In addition it will fill the financial intermediary gap in the 
country. Moreover, the findings signify the challenges of conventional banking practice that the authorities of the country and practitioners must avoid when Islamic banks are established. In addition, the practitioners need to focus on improving the current banking practice to avoid the challenges identified in the study. 


\section{Reference}

Ahrens, J., \& Hoen, H. W. (2013). Institutional Reform in Central economic challenges Edited by. (J. A. and H. W. Hoen, Ed.). New Haven: Routledge.

Akramov, K. T., \& Shreedhar, G. (2012). Economic Development, External Shocks, and Food Security in Tajikistan. IFPRI Discussion Paper, (1163). Retrieved from http://www.ifpri.org/sites/default/files/publications/ifpridp01163.pdf

Asia Plus. (2013, November 21). Tajikistan reportedly works out draft law on Islamic banking. News.tj. Dushanbe. Retrieved from $<$ http://news.tj/en/news/tajikistan-reportedly-works-outdraft-law-is/amicbanking>

Bibolov A. (2013). Tajikistan's banking system still far from ideal, says Tajik central bank head. Retrieved May 20, 2014, from http://news.tj/en/news/economy/finance/banks?page $=4$

Chorshanbiyev, P. (2013b). Tajikistan's financial system remains vulnerable to future shocks, says WB report. Asia-Plus - Weekly Newspaper.

Coleman, B. E., Goffe, V., Perolli, B., Usupova, M., Castillo, L. V., Holzhacker, H., ... Kappeler, A. (2012). Banking in the Eastern Neighbours and Central Asia: Challenges and Opportunities. Luxembourg.

Dellaert M. (2012). Challanges and Opportunities for Retail and Corporate Banks in a Fast changing and globalization. Belgium. Retrieved from www.mceama.com

Devan J. (2013). Barriers to Access to Payment Systems in Sending Countries and Proposed Solutions (Global Remitances Working Group). New York.

Dullien, S., Kotte, D. J., \& Priewe, J. (2010). The Financial and Economic Crisis of 2008-2009 and Developing Countries (Dullien, S). New York: United Nations Publications.

Ergasheva, Z. (2010, June 24). Tajikistan's banking system does not satisfy the needs of country's economy, ABT experts. "Asia-Plus," pp. 2009-2010. Dushanbe. Retrieved from http://old.news.tj/en/news/tajikistan-s-bankingsystem-does-not-satisfy-needs-country-s-economy-abt-experts

Falkingham, J., Baschieri, A., Evandrou, M., \& Grant, G. (2009). Left behind in transition? The well-being of older people in Tajikistan. Centre for Research on Ageing School of

Social Sciences. University of Southampton. Retrieved from http://r4d.dfid.gov.uk/PDF/Outputs/ESRC_DFID/60432_Left_Behind_Tadjikis tan.pdf

Honohan, P. (1997). Banking System Failures in Developing and Transition Countries: Diagnosis and Prediction. Switzerland. 
Jonson J. (2000). A Fistful of Rubbles: The Rise and Fall of the Russian Banking System,. USA: Cornell University Press.

Kidder L. (2013). Top Challenges Facing Financial Services in 2013. Retrieved August 16, 2016, from p://www.banktech.com/management-strategies/topchallenges-facing-financial-services-in-2013/a/d-id/1296034?.

Lima, Hecibedel, Olejnik, S. and Z. (2011). Banking in the Mediterranean Challanges and Opportunities.

Mallorca, P. De. (2007). Challenges and Opportunities for the Financial Sector and for Savings Banks. Spain. Retrieved from https://www.imf.org/en/News/Articles/2015/09/28/04/53/sp0302.

Matsuo, Albertazzi, Greathouse, While, B. and S. (2016). Ten Key Regulatory Challenges (Challenges of Financial Challenges). USA.

Mersch Y. (2015). Three challenges for the banking sector. In Cumberland Lodge Financial Sumit. Germany: European Central Bank, www.ecb.europa.eu. Retrieved from https://www.ecb.europa.eu/press/key/date/2015/ html/sp151112_1.en.html

Mountain, I. (2014). Addressing 4 key Challenges in the Financial Sector. UK.

Mrak M. (2000). Globalization: Trends, Challenges and Opportunites for Countries in Transition (Globalization and the Interation of Industry in the Region). Vienna.

Nesvetailova, A. (2014). Bank bailouts begin as Russia faces biggest challenge to date. City University London. Retrieved from http://theconversation.com/bank-bailouts-begin-as-russia-faces-biggestchallenge-to-date-35768.

Nyantakyi, E. B., Sy, M., \& Kayizzi-mugerwa, S. (2015). The Banking System in Africa: Main Facts and Challenges. Chief Economist Complex, 6(5), 1-16.

Okozaki K. (2007). Banking System Reform in CHina: The Challenges of Moving Toward a Market-Oriented Economy (Banking System reform in China). Banking System reform in China. Santa Monika.

Oliver, P. (2006). Purposive Sampling. In V. Jupp (Ed.),. The SAGE Dictionary of Social Research Methods. London, Engla: SAGE Publications, Ltd. Retrieved from http://dx.doi.org/10.4135/9780857020116.n162

Peng, Y. (2006). The Challenges of WTO entry to China's banking industry List of Abbreviations. Cambridge.

Pomfret, R. (2009). Central Asia and the Global Economic Crisis (No. 7). Eu -Central Asia Monitoring.

Qian, J. Q. J., \& Allen, F. (2011). China's Financial System: Opportunities and Challenges.

Business. University of Chikago. 
Ratings, F. (2014). RPT-Fitch: Kazakh Banks Cope with New Challenges, Legacy Problems. Retrieved August 15, 2016, from http://www.reuters.com/article/fitch-kazakh- banks-cope-with-new-challenidUSFit69655320140409. Retrieved from http://documents.worldbank.org/curated/en/2014/01/20302396/tajikistanmoderated-growth-heightened-risks.

Serrano S. (2010). Ethical Issues Facing the Banking Industry (Ethical Issues Facing the Banking Industry). Banking Industry. Retrieved from http://www.fidelisinstitute.org/article.php?se $=13 \& c a=22$

Shirinov A. (2013a). Agroinvestbonk has overcome crisis, says Tajik central bank head. Retrieved July 10, 2014, from http://news.tj/en/news.

Tadjbakhsh, S. (2008). International Peacemaking in Tajikistan and Afghanistan Compared : Lessons Learned and Unlearned.

Tobergte, D. R., \& Curtis, S. (2013). China's Banking Reform: Problems and Potential Solutions. Journal of Chemical Information and Modeling,53(9), 1689-1699. http://doi.org/10.1017/CB09781107415324.004.

Wehinger, G. (2009). The Financial Industry and Challenges Related to Post-Crisis Exit Strategies. Financial Market Trends, 2009(2), 1-18.

World Bank Goup Report No.6/2014. (2014). Tajikistan: Moderated growth, heightened risks

World Bannk. (2015). World Bank in Central Asia. Washington DC. Retrieved from http://www.worldbank.org/en/region/eca/brief/central-asia

World Islamic Finance Marketplace. (2016). CIS Region: Future Prospects for Islamic Finance. Malaysia. 